\title{
Neurodevelopment in Relation to Breastfeeding - Experiences Among Hungarian Preterm Infants at 12 Months of Corrected Age: A Cross-Sectional Study
}

Anna Szabina Szele ( $\sim$ szeleanna93@gmail.com )

University of Debrecen

Beáta Erika Nagy

University of Debrecen

\section{Research Article}

Keywords: preterm infants, low birth weight, breastfeeding, duration of breastfeeding, neurodevelopment outcomes

Posted Date: January 8th, 2021

DOI: https://doi.org/10.21203/rs.3.rs-140432/v1

License: (c) (i) This work is licensed under a Creative Commons Attribution 4.0 International License.

Read Full License 


\section{Abstract}

\section{Background}

Preterm and low birth weight infants are at higher risk of neurodevelopmental outcomes. Breastfeeding offers several beneficial aspects for them both physically and psychologically. This study aimed to describe the average neurodevelopmental outcomes of preterm infants and examine the associations between neurodevelopment and breastfeeding among Hungarian preterm infants at 12 months of corrected age.

\section{Methods}

One hundred fifty-four preterm infants with low birth weight $(<2500 \mathrm{~g})$ and gestational age $<37$ weeks and their mothers living in Hungary were participated in this cross-sectional examination. Bayley-III Screening Test (Bayley Scales of Infant and Toddler Development Screening Test, Third Edition) was administered to measure cognitive, language, and motor skills of infants. Breastfeeding data was obtained through parental anamnesis. To analyze data Mann-Whitney tests and Spearmen's rank correlation test were used to.

\section{Results}

Concerning risk of developmental delay, receptive and expressive language and fine motor subscales were the lowest. Examination of the duration of breastfeeding and neurodevelopmental performance identified higher neurodevelopmental outcomes in infants who were breastfed, significantly higher cognitive $(U=2047.5, p=0.023)$ and fine motor $(U=2096.0, p=0.037)$ skills were found. We identified significant positive correlations between the duration of breastfeeding and cognitive, expressive language and fine motor skills.

\section{Conclusions}

Breastfed infants had better cognitive and fine motor skills at 12 months of corrected age, but we cannot unambiguously conclude that the duration of breastfeeding had a sole positive effect on the neurodevelopment at 12 months of corrected age. With the Bayley-III Screening Test we could identify the most affected skills in terms of risk for developmental delay, which are needed to improve.

\section{Background}

According to the WHO (World Health Organization) definition, preterm birth means to be born before 37 completed weeks of gestation. Preterm birth is commonly associated with an overlapping perinatal risk, low birth weight. Each year approximately 15 million children are born preterm worldwide [1]. In Hungary, this proportion is $8 \%$ of the population (approximately 8.000 new-borns) [2]. Nutritional needs of premature babies significantly differ from their full-term counterparts, as they need more of any nutrient per unit body weight. This phenomenon is mainly due to the physical development of premature infants, 
i.e. the development of newly formed tissues is faster than in full-term counterparts. As well as, intercurrent diseases that often associated with preterm birth can also affect nutritional needs [3].

Breast-milk is the primary and most valuable source of nutrition and the main natural immune booster of both healthy new-borns and preterm infants, making them resistant to acute diseases and reducing the risk of developing pathological conditions [4]. Breastfeeding has beneficial effects on immunological, gastrointestinal, nutritional, and psychological aspects [5]. Regarding its components, the milk of mothers of preterm infants is different from mothers of full-term babies. It contains more protein, energy, fat and immunising agents, less lactose and more mineral salts [6]. Breastmilk protects the premature baby from gastrointestinal and respiratory infections, reduces the risk of developing NEC (necrotizing enterocolitis) and acute inflammatory bowel disease. In breast-milk fatty acids found to be easily digested for newborns, protective enzymes and hormones are essential for the growth and maturation of the digestive system, while lipids and fatty acids are indispensable for the balanced development of nervous system [5]. As a result, preterm infants experience fewer infections, spend fewer days in NICUs (neonatal intensive care units), and show better outcomes in tests of intellectual ability compared to formula-fed counterparts in later life [6].

However, the incidence and duration of breastfeeding are usually lower among premature infants compared to full-term babies. The lower incidence may be associated with breastfeeding challenges (e.g. maintaining milk supply), preterm delivery and immaturity of the new-born [7]. According to literature recommendations, exclusive breastfeeding is recommended for 6 months [8].

Despite of the benefits and protective factors of breastfeeding, preterm infants can be regarded as a vulnerable population, not only in terms of neurodevelopmental outcomes (apnoea, ROP, BPD, PH) but also in terms of intellectual development [9-11]. Therefore, in order to prevent future difficulties and developmental deficits, cognitive, motor end language screening of children at risk is especially significant as early as possible.

The objectives of this study are the description of neurodevelopmental outcomes on Bayley-III Screening Test subscales (cognitive, receptive and expressive, fine and gross motor skills) and the examination of the association between neurodevelopmental outcomes on Bayley-III Screening Test, breastfeeding and the duration of breastfeeding adjusted for premature and low birth weight children at 12 months of corrected age in a Hungarian sample.

\section{Methods}

\section{Sample}

154 low birth weight $(<2500 \mathrm{~g})$ and preterm infants ( $<37$ weeks) at 12 months of corrected age were examined at the Pediatric Psychology and Psychosomatic Unit of the Department of 
Pediatrics of the University of Debrecen between December 2017 and January 2019. All of them were delivered in the same maternity ward, at the Department of Obstetrics and Gynecology of the University of Debrecen. Only those infants were included in our study who underwent developmental assessment using the five distinct subscales of the Bayley-III Screening Test. Based on the Screening Test Manual, correction for prematurity was made [12]. In compliance with the Ethical Principles of the World Medical Association Declaration of Helsinki, the study was approved by the Medical Research Council of Hungary. Written informed consent was obtained from the parents of subjects'.

\section{Bayley-III Screening Test (Bayley Scales of Infant and Toddler Development Screening Test, Third Edition)}

In the identification of developmental difficulties and delays BSID-III (Bayley Scales of Infant and Toddler Development - Third Edition) is currently, the most advanced developmental tool for early prevention [13]. Both the full BSID-III and its screening test version were adapted and standardized in 2017 in Hungary. To assess the early developmental performance, we used the Bayley-III Screening Test, which allows the quick investigation of cognitive, language and motor skills of infants and toddlers between 1 to 42 months. Within the language scale, the test distinguishes receptive and expressive communication subscales, while within the motor scale differentiate fine and gross motor subscales. Its primary purpose is to determine that the development of child is appropriate or further diagnostically testing is needed. With the Screening Test, degree of risk for developmental delay can be distinguished: high, moderate and low risk for can be determined $[12,14]$.

\section{Developmental characteristics and the duration of breastfeeding}

Developmental characteristics of the child (gestational week, birth weight) were obtained from the clinical database of the Department of Pediatrics of the University of Debrecen. Information about early feeding, the duration of breastfeeding, and the socio-demographic characteristics was obtained based on a maternal anamnesis.

\section{Statistical analysis}

IBM SPSS Statistics v25 was used for statistical analysis. The normality of the sample was calculated by one-sample Kolmogorov-Smirnov test. Most of our data did not follow a normal distribution, so nonparametric tests were used. Mann-Whitney tests were used for group comparisons, and Spearmen's rank correlation test was used to measure the correlation between neurodevelopmental outcomes and duration of breastfeeding. P-values below 0.05 were considered statistically significant.

\section{Results}

\section{General data (means and standard deviations)}


All infants involved in the study $(n=154)$ were Hungarian with valid health insurance. The gender ratio was nearly balanced, 73 females and 81 males were examined. The mean birth weight of the children was between 540 and $2490 \mathrm{~g}(\mathrm{M}=1802.27, \mathrm{SD}=543)$, and the mean gestational age of the children was between 24 and 36 weeks $(M=32.81, S D=3.09)$. The main perinatal and socio-demographic characteristics of the sample are summarised in Table 1. 
Table 1

The main perinatal and socio-demographic characteristics of the sample

\begin{tabular}{|c|c|}
\hline \multicolumn{2}{|l|}{ Perinatal data, $n(\%)$} \\
\hline \multicolumn{2}{|l|}{ Gestational age (weeks) } \\
\hline very early (<28 weeks) & $15 / 154(9.74)$ \\
\hline early (28-31 weeks) & 24/154 (15.58) \\
\hline moderate (32-33 weeks) & $36 / 154(23.37)$ \\
\hline late (34-36 weeks) & 79/154 (51.29) \\
\hline \multicolumn{2}{|l|}{ Birth weight (g) } \\
\hline LBW (1500-2499 g) & 107/154 (69.48) \\
\hline VLBW (1000-1499 g) & 28/154 (18.18) \\
\hline ELBW $(<1000 \mathrm{~g})$ & 19/154 (12.33) \\
\hline \multicolumn{2}{|l|}{ Childbirth } \\
\hline Sectio caesarea & $105 / 154(68.18)$ \\
\hline Per vias naturales & $47 / 154(30.51)$ \\
\hline $\mathrm{N} / \mathrm{A}$ & 2/154 (1.29) \\
\hline \multicolumn{2}{|l|}{ Socio-demographic data } \\
\hline Maternal age at childbirth (years), $\mathrm{M} \pm \mathrm{SD}$ & $30.64 \pm 6.13$ \\
\hline Mother's educational level, n (\%) & $22 / 154(14.28)$ \\
\hline Primary & 61/154 (39.61) \\
\hline Secondary & $68 / 154(44.15)$ \\
\hline Higher & $3 / 154(1.94)$ \\
\hline \multicolumn{2}{|l|}{ N/A } \\
\hline \multicolumn{2}{|l|}{ Marital status, n (\%) } \\
\hline Single & 8/154 (5.19) \\
\hline Married & $98 / 154(63.63)$ \\
\hline Cohabiting & $35 / 154(22.72)$ \\
\hline In a relationship & 9/154 (5.84) \\
\hline $\mathrm{N} / \mathrm{A}$ & 4/154 (2.59) \\
\hline
\end{tabular}




\section{Neurodevelopment on Bayley-III Screening Test Subscales}

In our sample, the proportion of 'high risk for developmental delay' was negligible, ranging from $0 \%$ (cognitive subtest) to $3.24 \%$ (fine motor subtest). The proportion of 'moderate risk for developmental delay' was higher, ranging from $11.03 \%$ (cognitive subtest) to $24.02 \%$ (expressive communication subtest). Compared to the Hungarian standard full-term counterparts' values, our sample showed lower points for all subscales (see Table 2.).

Table 2

Neurodevelopmental performance on Bayley-III Screening Test subscales $(n=154)$

\begin{tabular}{|c|c|c|c|c|}
\hline & \multicolumn{4}{|c|}{ Mean subscale score Developmental delay } \\
\hline & $\begin{array}{l}\text { Hungarian } \\
\text { standard }\end{array}$ & $\begin{array}{l}\text { Mean } \\
\pm S D\end{array}$ & $\begin{array}{l}\text { 'High risk for } \\
\text { developmental delay', n } \\
\text { (\%) }\end{array}$ & $\begin{array}{l}\text { 'Moderate risk for } \\
\text { developmental delay', n (\%) }\end{array}$ \\
\hline $\begin{array}{l}\text { Cognitive } \\
\text { Subscale }\end{array}$ & $19.6 \pm 8.0$ & $\begin{array}{l}16.77 \\
\pm 1.44\end{array}$ & $0 / 154(0.00)$ & $17 / 154(11.03)$ \\
\hline $\begin{array}{l}\text { Receptive } \\
\text { Language } \\
\text { Subscale }\end{array}$ & $14.7 \pm 5.7$ & $\begin{array}{l}11.32 \\
\pm 1.60\end{array}$ & $4 / 154(2.59)$ & $32 / 154(20.77)$ \\
\hline $\begin{array}{l}\text { Expressive } \\
\text { Language } \\
\text { Subscale }\end{array}$ & $14.8 \pm 6.0$ & $\begin{array}{l}10.82 \\
\pm 1.92\end{array}$ & $4 / 154(2.59)$ & $37 / 154(24.02)$ \\
\hline $\begin{array}{l}\text { Fine Motor } \\
\text { Subscale }\end{array}$ & $15.9 \pm 6.1$ & $\begin{array}{l}12.26 \\
\pm 1.49\end{array}$ & $5 / 154(3.24)$ & $30 / 154(19.48)$ \\
\hline $\begin{array}{l}\text { Gross Motor } \\
\text { Subscale }\end{array}$ & $17.9 \pm 6.1$ & $\begin{array}{l}15.44 \\
\pm 1.76\end{array}$ & 2/154 (1.29) & 25/154 (16.23) \\
\hline
\end{tabular}

\section{Breastfeeding and neurodevelopmental performance}

In our sample, 99 (64.28\%) mothers were able to breastfeed their newborns, while 53 (34.41\%) mothers failed to start breastfeeding (they feed their babies with donor milk or preterm formula). In 2 cases we had no information about breastfeeding. Examining the relationship between breastfeeding and neurodevelopment, we found a higher average performance on the cognitive, expressive language and motor subcales. For the cognitive $(U=2047.5 ; p=0.023)$ and fine motor subscales $(U=2096.0 ; p=0.037)$, the differences were found to be significant between breastfed and non-breastfed children (see Table 3.). We also examined the effect of duration of breastfeeding period on the developmental performance. In our sample, breastfeeding period ranged from 2 weeks to 14 months. Using the Spearman's rank correlation test, we identified significant positive correlations between the duration of breastfeeding and cognitive $(r=0.218 ; p=0.07)$, expressive language $(r=0.209 ; p=0.01)$, and fine motor $(r=0.181, p=$ $0.026)$ skills. However, the value of the coefficient of determination $\left(r^{2}\right)$ is low for all three subscale 
variables $\left(r_{\operatorname{cog}}{ }^{2}: 0.04 ; r_{\exp }^{2}: 0.04 ; r_{f i n}^{2}: 0.03\right)$. Perinatal and socio-demographic characteristics of breastfed and non-breastfed groups are summarised in Table 4.

Table 3

Comparison of the neurodevelopmental outcomes of breastfed and non-breastfed infants (means, p-values)

\begin{tabular}{|llll|}
\hline & Means & \multicolumn{1}{c|}{$\begin{array}{l}\text { p-values } \\
\text { (test statistic) }\end{array}$} \\
\cline { 2 - 4 } & Breastfed & Non-breastfed & $\begin{array}{l}\text { Mann-Whitney test } \\
\text { p-value (U) }\end{array}$ \\
\hline Cognitive Subscale & 16.98 & 16.39 & $0.023(2047.5)^{*}$ \\
\hline Receptive Language Subscale & 11.27 & 11.45 & $0.137(3000.5)$ \\
\hline Expressive Language Subscale & 11.00 & 10.47 & $0.081(2179.5)$ \\
\hline Fine Motor Subscale & 12.43 & 11.98 & $0.037(2096.0) *$ \\
\hline Gross Motor Subscale & 15.59 & 15.15 & $0.141(2253.5)$ \\
\hline * $\mathrm{p}<0.05$, test statistics $(\mathrm{U})$ & & & \\
\hline
\end{tabular}


Table 4

Main characteristics of breastfed and non-breastfed infants (potential confounding factors)

Perinatal data, $n$ (\%)

Gestational age (weeks)

very early ( $<28$ weeks)

early (28-31 weeks)

moderate (32-33 weeks)

late (34-36 weeks)

Birth weight (g)

LBW (1500-2499 g)

VLBW (1000-1499 g)

ELBW $(<1000 \mathrm{~g})$

Gender distribution

boys $(n, \%)$

girls (n, \%)

Socio-demographic data

Maternal education, n (\%)

Primary

Secondary

Higher

N/A
Breastfed $(n=$

99)

$2 / 99$ (2.02)

$15 / 99(15.15)$

20/99 (20.2)

$62 / 99(62.62)$

$5 / 99$ (5.05)

$13 / 99(13.13)$

$81 / 99(81.81)$

$53 / 99(53.53)$

46/99 (46.46)
Non-breastfed $(n=$ 53)
13/53 (24.5)

9/53 (16.98)

16/53 (30.18)

15/53 (28.3)

24/53 (45.28)

$15 / 53$ (28.30)

14/53 (26.41)

$27 / 53$ (50.94)

26/53 (49.05)

Marital status, n (\%)

\section{${ }^{1}$ Note:}

alt runs on everything from my income and I can even save money.

bI don't have financial problems, but I can not save money.

${ }^{\mathrm{C}}$ My income just covers my expenses.

${ }^{\mathrm{d}}$ My income does not even cover my expenses. 


\begin{tabular}{|lll|}
\hline Perinatal data, $\boldsymbol{n}$ (\%) & $\begin{array}{l}\text { Breastfed }(\boldsymbol{n}= \\
\text { 99) }\end{array}$ & $\begin{array}{l}\text { Non-breastfed }(\boldsymbol{n}= \\
\mathbf{5 3})\end{array}$ \\
\hline Single & $5 / 99(5.05)$ & $3 / 53(5.66)$ \\
Married & $63 / 99(63.63)$ & $35 / 53(66.03)$ \\
\hline
\end{tabular}

Cohabiting

In a relationship

N/A

Subjective socioeconomic status (based on subjective evaluation)*

a
b
c
$22 / 99(22.22) \quad 13 / 53(24.52)$

$9 / 99(9.09)$

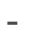

42/99 (42.42) 23/53 (43.39)

44/99 (44.44) 21/53 (39.62)

$11 / 99(11.11) \quad 5 / 53(9.43)$

$2 / 99(2.02)$

$4 / 53(7.54)$

\section{${ }^{1}$ Note:}

alt runs on everything from my income and I can even save money.

bI don't have financial problems, but I can not save money.

${ }^{\mathrm{C}} \mathrm{My}$ income just covers my expenses.

${ }^{d}$ My income does not even cover my expenses. 


\begin{tabular}{|l|l|}
\hline Perinatal data, $n(\%)$ & $\begin{array}{c}\text { Breastfed }(n= \\
99)\end{array}$ \\
\hline N/A & $\left.\begin{array}{c}\text { Non-breastfed }(n= \\
53\end{array}\right)$ \\
\hline${ }^{1}$ Note: & \\
\hline a It runs on everything from my income and I can even save money. \\
\hline b I don't have financial problems, but I can not save money. \\
\hline cMy income just covers my expenses. \\
\hline d My income does not even cover my expenses. \\
\hline
\end{tabular}

\section{Discussion}

\section{Neurodevelopmental outcomes on Bayley-III Screening Test}

The Bayley-III Screening Test, in addition to providing a comprehensive picture of cognitive, language and motor developmental characteristics in early childhood, is able to screen for children at risk for delayed development, thus differentiating children at high, moderate, or low risk for developmental delays. However, based on its results, no child can be considered to be delayed in neurodevelopment [12]. Regarding the neurodevelopmental results of our sample, the lowest performance was identified on the receptive, expressive language and fine motor subscales. This result is consistent with the most literature findings. It is well-known, preterm infants have significantly lower neurodevelopmental skills in early ages compared to their full-term counterparts. Difficulties in the motor skills may negatively affect the communication skills, such as joint attention and face-to-face interaction (complicating the process of language acquisition) [15-16].

\section{The connection between neurodevelopment, breastfeeding and the duration of breastfeeding}

According to the results of Mann-Whitney tests, breastfed children had better cognitive and fine motor skills at 12 months of corrected age. The more the duration of breastfeeding was the better performance measured on cognitive, expressive and fine motor subscales. However, the low coefficients of determination $\left(\mathrm{r}^{2}\right)$ indicate that other factors and variables may contribute to the neurodevelopmental performance. A potential confounding factor can be, for example, the birth weight, duration of pregnancy, sex, duration of hospitalization, family socioeconomic condition just to mention a few. Thus, we cannot conclude that the increase in neurodevelopment is due to breastfeeding unequivocally. With breastfeeding, mothers provide a cognitively more stimulating environment for their babies, so not only the components of breastmilk but the family environment and the mother-child interaction also contribute to the development of the child. 
Our results are consistent with literature findings that emphasise both the short- and long-term positive effects of breastfeeding on the child's psychological and intellectual development. Jardí et al. [17] found that exclusive breastfeeding for at least 4 months results in a higher neurodevelopmental index at 6 and 12 months of age. The meta-analytical study of Horta et al. [18] focused on the investigation of long-term effects, their results emphasized that children who were breastfed in infancy, significantly performed better on intelligence tests (mean difference 3.44 points) in childhood and adolescence compared to nonbreastfed counterparts. Breastfed preterm infants with ELBW are characterised by higher mental, motor and behavioural performance at 18 and 30 months of age [19].

Among preterm infants, examining the effects of exclusive breastfeeding and formula feeding, differences can be identified also. According to the study of Wei Li et al. [20], among children with a gestational age of 28 and 30 weeks, breastfeeding played an important role in weight gain, reduced feeding intolerance, the incidence of NEC, and length of hospital stay. No correlations were found among formula milk feeding group. Lucas et al. [21] found that breastfed preterm infants perform better on intelligence tests later in life compared their formula-fed counterparts. Overall, we can conclude that breastfeeding for preterm infants is beneficial not only from a nutritional, gastrointestinal, immunological point of view, but developmental and psychological also.

\section{Limitations}

One of the potential limitations of our study is the absence of adjusted control group. Description of the neurodevelopmental outcomes we used the Hungarian standard values as a reference, but the comparison with it should be treated with caution, as children were included in standardization process from 2 to 42 months of age. Another limitation of our research is that potential confounding factors that may affect neurodevelopmental performance were not statistically controlled. To overcome this limitation, we re-assess the children in our sample at the 24 months of corrected age and take into consideration other variables when evaluate the development.

\section{Conclusions}

Due to the consequences of prematurity, premature babies regarded as a vulnerable population [22], who begins the early life with a neurodevelopmental disadvantage. Breastfeeding can help them redressing this disadvantage. For public health, it is essential to draw the attention to the importance of breastfeeding, to inform mothers about its extensive positive effects on the child and mother, and to involve premature babies in psychological screening as soon as possible. Bayley-III Screening Test is an excellent tool to identify those neurodevelopmental areas where the interventions are needed. In summary breastfed infants have shown significantly better cognitive and fine motor skills in the Bayley-III Screening Test at 12 months of corrected age. However, these findings should be treated with caution, because of the potential confounding factors. The importance of the reported study is increased by that it is one of the first pieces of research with Bayley-III Screening Test in Hungary.

\section{Abbreviations}


BPD: bronchopulmonary dysplasia; BSID-III: Bayley Scales of Infant and Toddler Development - Third Edition; ELBW: extremely low birth weight; LBW: low birth weight; NEC: necrotizing enterocolitis; N/A: missing data; NICU: neonatal intensive care unit; PH: pulmonary hypertension; ROP: retinopathy of prematurity; VLBW: very low birth weight; WHO: World Health Organization

\section{Declarations}

\section{Ethic approval and consent to participate}

The study was approved by the Medical Research Council of Hungary in compliance with the Ethical Principles of the World Medical Association Declaration of Helsinki (12053-2/2018/EKU). Informed consent were obtained from parents of subjects.

\section{Consent for publication}

Not applicable.

\section{Availability of data and materials}

Not applicable.

\section{Competing interests}

The authors declare that they have no competing interests.

\section{Funding}

Not applicable.

\section{Authors' contribution}

A.Sz.Sz. and B.E.N. designed the study and wrote the manuscript. A.Sz.Sz. carried out the developmental assessments, prepared tables 1-4. and was responsible for data analysis. All authors contributed to interpretation, read and approved the final manuscript.

\section{Acknowledgements}

The authors would like to thank all the children and parents for their participation. We are grateful to our colleagues at the Pediatric Psychology and Psychosomatic Unit of the Department of Pediatrics of the University of Debrecen.

\section{Authors' information}

${ }^{1}$ Faculty of Medicine, Pediatric Psychology and Psychosomatic Unit of the Department of Pediatrics, Kálmán Laki Doctoral School of Biomedical and Clinical Sciences, University of Debrecen, Debrecen, 
Hungary. ${ }^{2}$ Faculty of Medicine, Pediatric Psychology and Psychosomatic Unit of the Department of Pediatrics, University of Debrecen, Debrecen, Hungary.

\section{Footnotes}

Not applicable.

\section{References}

1. WHO. Preterm birth. Key facts. https://www.who.int/news-room/fact-sheets/detail/preterm-birth/ (2018). Accessed 17 Mar 2020.

2. UNICEF Office of Research. Child well-being in rich countries. A comparative overview. Innocenti Report Card 11. 2013. https://www.unicef-irc.org/publications/pdf/rc11_eng.pdf. Accessed 07 Jan 2020.

3. Decsi T. Csecsemőtáplálás. In: Maródi L, editor. Gyermekgyógyászat. Budapest: Medicina Könyvkiadó Zrt.; 2013. pp. 94-108.

4. Gárdos L, Kovács T, Nádor Cs, et al. Az egészséges újszülött és koraszülött táplálás szakmai irányelveken alapuló gyakorlati útmutatója. 2018.

http://www.gyermekalapellatas.hu/aktualitasok/az_egeszsges_ujszulott.html/. Accessed 07 June 2020.

5. EFCNI. Breast milk for preterm babies, More than a mental. 2020. https://www.efcni.org/wpcontent/uploads/2020/08/2020_EFCNI_Stillbroschuere_englisch.pdf. Accessed 08 Aug 2020.

6. Heffner-Sarkar S, Kulcsár J. PICi füzet, nagy segítség. Budapest: Koraszülöttekért Közhasznú Egyesület; 2015.

7. Callen J, Pinelli J. A review of the literature examining the benefits and challenges, incidence and duration, and barriers to breastfeeding in preterm infants. Adv Neonatal Care. 2005;5:72-88. https://doi.org/10.1016/j.adnc.2004.12.003.

8. Kramer MS, Kakuma R. The Optimal Duration of Exclusive Breastfeeding. In: Pickering LK, Morrow AL, Ruiz-Palacios GM, et al., editors. Protecting Infants through Human Milk. Adv Exp Med Biol. 2004;554:63-77. https://doi.org/10.1007/978-1-4757-4242-8_7.

9. Choi EK, Shin SH, Kim EK. et al. Developmental outcomes of preterm infants with bronchopulmonary dysplasia-associated pulmonary hypertension at 18-24 months of corrected age. BMC Pediatr. 2019;19:26. https://doi.org/10.1186/s12887-019-1400-3

10. Potijk MR, de Winter AF, Bos AF, et al. Higher rates of behavioural and emotional problems at preschool age in children born moderately preterm. Arch Dis Child. 2012; 97:112-17. DOI: 10.1136/adc.2011.300131.

11. Woythaler MA, McCormicck MC, Smith VC. Late preterm infants have worse 24-month neurodevelopmental outcomes than term infants. Pediatrics. 2011;127:2009-3598. https://doi.org/10.1542/peds.2009-3598. 
12. Bayley N. Bayley Scales of Infant and Toddler Development, 3rd ed. Screening Test Manual. San Antonio: TX: NCS Pearson Inc; 2005.

13. Bayley N. Bayley Scales of Infant and Toddler Development, 3rd ed. Administration manual. San Antonio: TX: Harcourt Assessment; 2006.

14. Kő N, Mészáros A, Rózsa S, et al. Bayley Csecsemő és Kisgyermek Skálák, Harmadik Kiadás. Szűrőteszt. Tesztfelvételi Kézikönyv. Budapest: OS Hungary Tesztfejlesztő Kft.; 2017.

15. Benassi E, Savini S, Iverson JM, et al. Early communicative behaviors and their relationship to motor skills in extremely preterm infants. Res Dev Disabil. 2016;48:132-44. https://doi.org/10.1016/j.ridd.2015.10.017.

16. Sansavini A, Pentimonti J, Justice L, et al. Language, motor and cognitive development of extremely preterm children: modeling individual growth trajectories over the first three years of life. J Commun Disord. 2014;49:55-68. https://doi.org/10.1016/j.jcomdis.2014.02.005.

17. Jardí C, Hernández-Martínez C, Canals J, et al. Influence of breast-feeding and iron status on mental and psychomotor development during the first year of life. Infant Behav Dev. 2018;50:300-10. DOI: 10.1016/j.infbeh.2017.05.009.

18. Horta $\mathrm{BL}$, de Mola CL, Victoria CG. Breastfeeding and intelligence: a systematic review and metaanalysis. Acta Paediatr. 2015;104:14-9. https://doi.org/10.1111/apa.13139.

19. American Academy of Paediatrics, Breastfeeding and use of human milk. Pediatrics. 2012;129:82741. DOI: 10.1542/peds.2011-3552.

20. Wei Li Y, Ying Yang C, Yang L, et al. Effect of breastfeeding versus formula milk feeding on preterm infants in the neonatal intensive care unit. Zhongguo Dang Dai Er Ke Za Zhi. 2017;19:572-75. DOI: 10.7499/j.issn.1008-8830.2017.05.019.

21. Lucas A, Morley R, Cole TJ, et al. Breast-milk and subsequent intelligence quotient in children born preterm. Lancet. 2009;339:261-64. https://doi.org/10.1016/0140-6736(92)91329-7.

22. Aarnoudse-Moens CS, Weisglas-Kuperus N, van Goudoever JB, et al. Meta-analysis of neurobehavioral outcomes in very preterm and/or very low birth weight children. Pediatrics. 2009;124:717-28. https://doi.org/10.1542/peds.2008-2816. 